\title{
DIE AFRIKAANSE CALVINISTIESE BEWEGING
}

\section{(1) OPROEP}

Calvinistiese aksie is gedurende 'n sekere tydperk in ons geskiedenis min of meer met die Gereformeerde Kerk vereenselwig. Burgersdorp (vroeër) en Potchefstroom (later) sou dan die Suid-Afrikaanse Calvinisme verteenwoordig. „Potchefstroom" veral het vir sommige mense bykans sinoniem geword met „Calvinisme"-vera ook in kringe wat miskien self nie te vee geweet het van en alte geinteresseerd was in die Calvinistiese lewens- en wêreldbeskouing nie.

In hoeverre lede van die Gereformeerde Kerk, hopelik in alle beskeidenheid, hierdie opvatting mog deel, laat ons daar. Insoverre daar waarheid in steek, mag ons vertrou dat hulle bewus was (en is) van die groot verantwoordelikheid wat daarmee op hulle geplaas is. Uitgaande van die veronderstelling - waartoe die geskiedenis wel steun verleen-dat die Gereformeerde Kerk 'n nie onaansienlike rol gespeel het in die verbreiding van die Calvinistiese beginsels en die bevordering van Calvinistiese aksie in Suid-Afrika, wil ons dadelik beklemtoon dat die Calvinistiese beginsels self allermins toelaat dat sodanige aksie deur die mure van 'n kerk begrens kan en mag word nie. 'n Calvinisme wat nie soek om die eer van God op iedere terrein van die lewe te bevorder nie, sou aan sy aard ontrou wees.

Vandaar die nadruk wat in die Gereformeerde optrede in hierdie verband steeds geval het op die Christelike maatskappy, met name op die Christelike onderwys. Vandaar ook die onophoudelike poginge om die kring wyer te span as net die van die kerklik gereformeerde. Want ons aanvaar graag en dankbaar die feit dat ons volksplanting in die teken van die Calvinisme gestaan het en dat daarvan baie trekke dwarsdeur ons troebele volks- en kerkgeskiedenis bewaar gebly het. Gode die eer

Die geskiedenis van Calvinistiese or ganisasies in ons land kan in hooftrekke soos volg saamgevat word:

1. Die Vereniging vir C.H.O., gestig te Potchefstroom na die inkorporasie van die Literariese Afdeling van die Teologiese.
Skool by die Universiteit van Suid-Afrika as „Die P.U.K. vir C.H.O.". Sy besondere taak was, soos sy naam aandui, die bevordering van Christelike Hoër Onderwys en, meer in besonder, die belange van die P.U.K.

2. Die Christelike Unie, waarin die Vereniging vir Christelike Hoër Onderwys later opgegaan het. Sy doelstelling was breèr: "bestudering, propagering en toepassing van die "Christelike beginsels volgens die Calvinistiese lewens- en wêreldbeskouing".

3. Die Calvinistiese Bond (1929). Die Christelike Unie is ontbind met die uitgesproke doel om die samewerking van alle Calviniste in die land te verkry. Hiervan was die Calvinistiese Bond die resultaat.

4. Die Calvinistiese Studiekring, later Die Calvinistiese Unie genoem (1942) wat die goeie werk van die Calvinistiese Bond probeer voortset het.

Elkeen van hierdie organisasies het sy tyd gehad en in mindere of meerdere mate die doel gedien waarvoor dit in die lewe geroep is. Die Calvinistiese strewe het geleidelik in wyer kringe onder ons volk weerklank en warme voorstanders gevind. Dit geld miskien in besonder van laasgenoemde organisasie (die Calvinistiese Unie), wat o.a. 'n eie uitgewersmaatskappy (Sacum) in die lewe geroep het.

Ongelukkig was 'n skeiding van die weë aanstaande eers binne Sacum en einde lik binne die C.U. self. N.G. -lede het tot die sienswyse geraak dat ' $n$ eie Calvinistiese organisasie binne kerklik-N.G.-kring, voorlopig altans, beter aan hul eiesoortige probleme sal beantwoord en het gevolglik verkies om daardie koers in te slaan. Prakties kom dit op hierdie tydstip derhalwe daarop neer dat „Potchefstroom" weer "n keer op eie inisiatief aangewys is, en dit wil ons aanvaar as 'n beskikking van Godsweë. Sonder om een oomblik ons tradisionele, prinsipiële koers te verlaar: ons wil saamwerk met ieder en elk wat hom op dieselfde standpunt plaas. Ons wil dit dan ook baie duidelik stel: onder "Potchefstroom" verstaan 
ons almal wat ondersteuners is van die koers en rigting wat met hierdie naam aangedui word, waar hulle ook mag woon. „Potchefstroom" is vir ons hier 'n simboliese naam.

Ons spreek van ,beweging" en nie van ,bond" of iets dergeliks nie, omdat ons duidelik wil laat verstaan dat ons hier met 'n liggaam te doen het wat wil beweeg, wat tot dade wil oorgaan en dit nie by goeie voornemens wil laat nie. Elkeen weet egter dat enige beweging per slot van rekening deur 'n kern gedra word. Hierdie beweging wil groot dinge doen en sal baie geld nodig hê. Daarom word van sy lede 'n aansienlike jaarlikse bydrae gevra. Is iemand die saak egter goedgesind sonder dat hy die minimum-ledegeld kan betaal, kan hy met 'n kleiner bydrae begunstiger word en so sy deel bydra.

Is so 'n Beweging noodsaaklik naas die arbeid van die Kerk? Beslis, ja! Hierdie beweging oefen sy werksaamheid uit op die terrein van die maatskappy, en niemand sal kan ontken dat Christelike maatskaplike aksie in ons vaderland noodsaaklik is nie. Daarsonder word die Kerk op 'n puinhoop gebou soos in die dae van Serubbabel en Josua. Die stad self moet opgebou en sy mure herstel word-dit is die taak van maatskaplike aksie.

Wat is die essensiële voorwaardes vir die welslae van ons Beweging? Afgesien van die onmisbare seen van die Here kan ons veral vyf essensiële sake noem:

1. Elke lid van die Beweging moet getrou en aktief werksaam wees. Ons moet meer op kwaliteit as op kwantiteit kan staatmaak.

2. Daar moet vaste en/of tydelike organiseerders wees.

3. Daar moet konkrete doeleindes wees waarvoor gewerk word, soos deur die kongres van tyd tot tyd bepaal.

5. Om dit alles te kan doen moet die Beweging oor genoegsame middele beskik. Daar moet werklik offers gebring word.

As die harte warm is vir die saak van die Koning, kom die offers vanself; maar omgekeerd: deur die hand aan die ploeg te slaan en te werk word die hart warm.

Gaan u saam beweeg? Hier is 'n grootse onderneming vir 'n groot saak. U roel saam met ons, kom doen saam. Hierdie roepstem mag aan $u$ nie verbygaan nie.

DIE BESTUUR.

\section{(2) STATUTE VAN DIE AFRIKAANSE CALVINISTIESE BEWEGING}

\section{NAAM.}

Die naam van die organisasie sal wees: DIE AFRIKAANSE CALVINISTIESE BEWEGING.

\section{GRONDSLAG.}

Die grondslag van die Beweging is die Woord van God soos vertolk deur die Gereformeerde Belydenisskrifte.

\section{DOEL.}

Die doel van die Beweging is: die bestudering, propagering en toepassing van die Skrifbeginsels vir die verskillende lewensterreine volgens die Calvinistiese lewens- en wêreldbeskouing.

\section{MIDDELE.}

1. Aktivering van die kragte van Calviniste in Suid-Afrika deur die werwing van lede en stigting van plaaslike aksiekomitees oor die hele land, waar en sover moontlik deur die aanstelling van vaste en/ of tydelike organiseerders.

2. Beinvloeding deur woord en geskrif van ons volksontwikkeling in Calvinistiese rigting en bestryding van alle nadelige invloede.

3. Bevordering van Christelike wetenskapsbeoefening, onderwys en opvoeding, in ooreenstemming met ons belydenis.

4. Ondersteuning, finansieël en andersins, van beweginge en organisasies wat op dieselfde beginselgrondslag staan.

5. Versameling van geldelike middele ter finansiëring en ondersteuning van aksie in bogenoemde rigtinge.

\section{AARD EN AANSPREEKLKKHEID.}

Die Beweging is 'n afsonderlike regspersoon, en sy lede is nie aanspreeklik vir sy skulde nie behalwe tot die bedrag van hulle jaarlikse ledegeld.

\section{LEDE EN LEDEGELD.}

1. Die Beweging verwelkom as lede almal wat die grondslag en doelstelling onderskrywe en hulle aan die bepalinge van die Statute onderwerp.

2. Lidmaatskap word deur die Bestuur toegeken.

3. Ledegeld is: minstens en pond (fl) per maand. 
VII. BEGUNSTIGERS.

Persone wat minder as die voorgeskrewe minimum aan ledegeld bydra, sal beskou word as begunstigers van die Beweging en sal alle omsendbriewe ontvang.

\section{GEAFFILIEERDE VERENIGINGE.}

Liggame of vereniginge wat op dieselfde beginselgrondslag staan, kan met goedkeuring van die Bestuur met die Beweging affilieer en dra dan minstens twaalf pond ( $f 12)$ per jaar by. So 'n liggaam of vereniging mag 'n persoon benoem om namens hom op te tree en te stem op kongresse.

\section{KONGRES.}

1. Aard. Die Kongres is 'n al gemene vergadering van die lede en word minstens eenmaal per jaar gehou op 'n tyd en plek deur die Bestuur bepaal.

2. Stemreg. Elke lid wat sy/haar geldelike verpligtinge nagekom het, sal volle sittingsreg op die Kongres hê.

3. Kworum. Die kworum van die Kongres is 25 lede.

4. Meerderheid. In alle gevalle beslis die volstrekte meerderheid van uitgebragte stemme, behalwe in die gevalle wat genoem word in art. XIV, 1 en 2, en XV, 1 .

5. Staking van stemme. Wanneer die stemme staak, het die Voorsitter 'n beslissende stem.

6. Gesag. Die Kongres is die hoogste gesag in die Beweging.

7. Leiding. Die Bestuur neem die leiding by kongresse.

8. Reglement. Die Kongres stel sy eie huishoudelike reglement op.

\section{STREEKSKONFERENSIES}

Die Bestuur kan op eie inisiatief of op versoek van lede streekskonferensies organiseer. Besluite wat hier geneem word dien as adviese aan die Kongres.

\section{BESTUUR.}

1. Samestelling. Die Bestuur bestaan uit Voorsitter, Vise-Voorsitter, Sekretaris, Penningmeester en nog vyf ander lede.

2. Verkiesing. Die Kongres kies die Voorsitter en vier ander lede. Hierdie lede koöpteer nog vier, en daarna konstitueer die Bestuur homself verder.
3. Vakatures. Enige vakature wat ontstaan, word deur die Bestuur self aangevul.

4. Kworum. Vyf lede vorm 'n kworum.

5. Magte. Die Bestuur tree in alle sake namens die Beweging op wanneer die Kongres nie in sitting is nie, gee algemene leiding aan die Beweging en wend alle geoorloofde poginge aan om die doelstellinge te verwesenlik.

6. Verslag. Die Bestuur lewer jaarliks verslag aan die Kongres.

7. Subkomitees. Die Bestuur mag subkomitees vir spesiale take benoem. Hierop mag ook lede dien wat nie bestuurslede is nie.

8. Administrasie. Die Bestuur mag onder nadere goedkeuring deur die Kongres, reëlinge tref vir die uitvoering van sy administratiewe pligte.

9. Amptenare. Die Bestuur mag, onder nadere goedkeuring van die Kongres, vaste en/of tydelike amptenare benoem as die middele dit toelaat.

10. Eerste Bestuur. Die eerste Bestuur word gekies op die stigtingsvergadering en bly in funksie tot die eersvolgende kongres.

\section{DAgbestuUR}

1. Lede. Die Bestuur benoem uit sy lede 'n Dagbestuur van vyf.

2. Taak. Die Dagbestuur tree op in verband met spoedeseinde sake en behartig in die algeneem die belange van die $\mathrm{Be}-$ weging, sover moontlik met raadpleging van die ander bestuurslede.

3. Verslag. Aan die Bestuur moet volledig verslag gedoen word van alle handelinge.

\section{PLAASLIKE \\ AKSIEKOMITEES}

1. Stigting. Die Bestuur, of lede met toestemming van die Bestuur, neem inisiatief in die stiging van plaaslike $A k-$ siekomitees.

2. Taak. Dit is die taak van Aksiekomitees om in hul omgewing so aktief moontlik te werk ter verwesenliking van die doelstellinge van die Beweging.

3. Lede. 'n Aksiekomitee moet bestaan uit minstens drie lede. 
XIV. WXSIGING VAN STATUTE.

1. Art. II en art XIV, 1 mag nooit gewysig word nie.

2. Art. III en art. XIV, 1 mag slegs deur 'n twee-derde meerderheid op 'n kongres gewysig word.

3. Ander artikels. Ander artikels as die onder XIV, 1 en 2 genoemde mag deur'n gewone meerderheid op 'n kongres gewysig word.

4. Kennisgewing. Van alle voorgestelde wysiginge moet minstens twee maande voor die sitting van die Kongres aan alle lede skriftelik kennis gegee word.

\section{ONTBINDING.}

1. Meerderheid. Die Beweging kan alleen ontbind word as 'n tweederde meerderheid op 'n Kongres ten gunste daarvan is.

2. Bates. Ingeval die Beweging ontbind word, sal die bates bestee word volgens gewone meerderheidsbesluit van die Kongres.

3. Naskrif. Op die stigtingsvergadering (20 Maart 1953) is die statute goedgekeur soos deur die voorlopige Bestuur opgestel, met die verstande dat die Bestuur veranderinge kan aanbring in die lig van die besprekinge.

Die Bestuur het die statute nou na rype oorleg in die bestaande vorm gebring en sal dit so aan die eerste Kongres D.V. voorlê. Vanselfsprekend geld nou verder art. XIV van die statute, waar die moont- likheid van wysiginge veronderstel word Op die eerste Kongres sal egter ook wat die bewoording van artikels II en II (grondslag en doel) betref, desvereis veranderinge aangebring kan word as lede ook in hierdie geval tydig van die voorgestelde veranderinge aan die sekretaris kennisgee.

Die Bestuur sal ook aan die Kongres 'n konsep-program van aksie voorlê.

Aangesien die statute voorsiening maak vir 'n Bestuur van nege lede is nog twee lede gekoöpteer by die oorspronklike sewe, sodat die Bestuur nou bestaan uit: Prof. J. C. van Rooy, prof. D. J. van Rooy, prof. H. G. Stoker, dr. P. W. Vorster prof. S. du Toit, dr. S. P. van der Walt, dr. J. A. Schutte, dr. J. H. Coetzee, ds. P. W. Buys.

Gelde is vooruitbetaalbaar, maande liks of jaarliks. As dit maandeliks gebeur word aftrekorders van die bank verkies. Alle tjeks, posorders, wissels, aftrekorders ens. moet betaalbaar gemaak word aan Die Afrikaanse Calvinistiese Beweging (Bankiers: Volkskas Beperk, Potchefstroom.).

'n Aansoekvorm vir lidmaatskap en, in aftrekordervorm is agter in aangeheg.

Rig alle korrespondensie aan:

Die Sekretaris,

Die Afrikaanse Calvinistiese

Beweging.

P.U. vir C.H.O.,

Potchefstroom. 